\title{
Requirements and Benefits for
}

\section{Academic Librarians: 1959-1979}

This study examines job advertisements for academic librarians published in three journals between 1959 and 1979. It attempts to discover basic changes in the requirements demanded of, and benefits offered to, job candidates over this time period. Announcements were analyzed in terms of their requirements for education, experience, qualifications, and responsibilities and their offers of salary and faculty status. The study concludes that, although academic librarians were expected to bring more to their jobs in 1979 than in 1959 , salaries in real dollars showed no appreciable increase, and faculty status was not explicitly offered in most cases.

$\mathbf{P}$ ROFESSIONAL LITERATURE of the past twenty years has outlined certain trends that have had a good deal of impact on the academic librarian's work environment. The financial climate changed markedly with the ample budgets of the fifties and sixties shrinking to austerity levels by the seventies. A more democratic concept of education produced a broader-based student body; a larger proportion of college students was drawn from the adult working population. Trends in curriculum emphasized individual research skills at both the undergraduate and graduate levels. Modern technology invaded the campuses; computers assumed more and more of the routine chores formerly performed by humans. Published material not only increased exponentially, but also became international in scope and variable in form.

All of these changes had implications for the academic librarian. As a result of budgetary problems, fewer professionals were employed, and paraprofessionals began to perform the libraries' more routine duties. The use of paraprofessionals resulted in a recognition that the professional's contribution was intellectual rather than clerical in nature.

Mary Baier Wells is a record associate at Oppenheimer Law Firm, St. Paul, Minnesota. Research for this study was funded by a grant from the University of Minnesota Computer Center.
The changing student body and the researchoriented curriculum called for librarians to develop bibliographic instruction programs and to perform more in-depth reference work. The international growth of publication meant that librarians needed foreignlanguage proficiency. The technology explosion gave librarians new opportunities for service, but also required that they master unfamiliar skills like online searching and microforms management. Since collection development took place under budgetary constraints in order to support a researchoriented curriculum, librarians were often expected to have a strong subject background and to initiate and maintain close ties with faculty who could assist them in their selections from an ever-increasing amount of material. Formerly, librarians had been expected to collect, preserve, and organize collections of books. In the last few years, however, they have come to assume additional roles: communicator, information specialist, manager, and scholar.

If the perceptions in the literature are accurate, more is being demanded now of academic librarians than when libraries were simply depositories of books. If more is required, it follows that more should be offered in compensation. The purpose of this study is to ascertain whether empirical evidence supports the belief that academic librarianship has changed in terms of the requirements de- 
manded of, and the benefits offered to, its practitioners, and if it has, to attempt to pinpoint some of the changes.

Specifically, the study examines three hypotheses:

1. Librarians are expected to bring more to their jobs in education, experience, and qualifications.

2. The nature of the librarian's work has expanded in scope and complexity.

3. Librarians are being offered more in return for meeting these higher standards.

\section{METHOD}

A study of job advertisements was initiated with the goal of ascertaining whether these notices supported the three hypotheses listed above.

Five years, 1959, 1964, 1969, 1974, and 1979 , were chosen to represent the twentyyear span from 1959 to 1979 . The years chosen were evenly spaced to reflect fluctuations in the job market and to indicate when certain changes began to appear. Three journals were used as sources of job announcements: Library Journal, ALA Bulletin/American Libraries, and College and Research Libraries/College and Research Libraries News. All postings for academic librarians from the journals and years listed were extracted and analyzed. Advertisements were used only once even if they appeared in more than one publication. A notice was selected for inclusion only if the job title or responsibilities implied that the position advertised was not primarily administrative or technical in nature. Notices selected were analyzed in terms of job type, education, qualifications, responsibilities, status, and salary.

The type of job could sometimes be discerned by its title (catalog librarian, for example), but when the title was vague, a type was assigned by examining the responsibilities listed in the advertisement. The education component was broken down into two groups: the type of library degree specified and the type of subject master's degree required. Those persons seeking professional library employment were assumed to be college graduates. Qualifications and responsibilities were noted as they appeared, and were included regardless of whether they were listed as required, desired, or preferred. Status was noted as faculty, civil ser- vice, or a professional/academic classification between the two. The last component noted was the salary or range of salaries for each position.

After all of the data was accumulated, it was broken down into variables and coded so that it could be punched onto Hollerith cards. Nine job types emerged as the data were analyzed. When the word librarian was used without specified job responsibilities, or when widely diverging responsibilities such as cataloging and reference were expected of one person, general librarian was used as the job type. A subject specialist was defined as a librarian with a strong subject background whose responsibilities cut across the traditional public and technical services boundary. Branch head was included as a job type because many positions combined administrative and library duties and thus fit into the scope of this study.

Library education was grouped into four categories: unspecified library coursework, a bachelor's degree in library science, a general MLS, or an ALA-accredited master's. The next variable, the subject master's degree, was broken into two categories depending on whether or not the announcement specified a subject. The same principle was applied to library experience. A distinction in coding was made on the basis of whether the advertisement asked for general or specialized library experience. In all cases, 0 was the code used to indicate that a variable was not mentioned in the notice.

The next eight variables dealt with the qualifications that candidates needed to bring to the job. Some of these variables are self-explanatory, but others will need definition. Computer expertise encompassed training or experience with computers, bibliographic utilities, or databases for information retrieval. Subject background or training included an undergraduate degree or graduate work short of the master's in a particular subject. A-V knowledge was a wide-ranging category, including knowledge, training, or experience with audiovisual machinery, media production, or the bibliographic control of multimedia materials. Specific library expertise meant specialized knowledge of library practices and was expressed with phrases like "knowledge of AACR" or "experience with LCSH." Com- 


\section{2 / College \& Research Libraries • November 1982}

municative ability concerned skill in relating to faculty, students, and co-workers. Administrative or supervisory ability had to do with experience or training in personnel, budgeting, planning, or business management. Each of these variables was coded with a 0 if the qualification was not desired, and a 1 if it was.

The next variable, sex, indicated whether the employer specified a preference for a man or a woman for the job. Zero indicated no preference; 1 was the code for a man, and 2 for a woman.

Successive variables were concerned with job responsibilities. Some definition will again be necessary. Processing and acquisitions were distinguished by the fact that the former had to do with the handling of books after their arrival at the library, and the latter was concerned with preorder searching, verification, and order-file maintenance. Collection development entailed choosing individual titles, and more importantly, developing a focused, well-directed plan for the growth of the collection as a whole. Bibliographic instruction included formal courses, orientation activities, and production of guides and bibliographies. A-V work meant handling audiovisual machines as well as multimedia products. Computer work included design or use of automated library operation systems, informationretrieval systems, or bibliographic utilities. Administrative duties encompassed planning, budgeting, and management. Personnel work, defined as training and supervision of employees, was separated from administrative duties. Variables such as work in a specialized subject or work with specialized materials were indicated in addition to other duties. Phrases like "reference with government documents" or "cataloging musical scores" illustrate why these distinctions became necessary.

The final variables had to do with benefits. Status was divided into civil service, professional/academic, and faculty categories. Salary was coded as it appeared in the job advertisement. If a range of salaries was specified, only the minimum was coded, since it was the only one that could be determined with any certainty. A standardized salary was calculated by using a computer program to divide each salary by the consumer price index for the year in which it was offered. The result was that the salaries were adjusted to account for inflation and were expressed in 1967 dollars, giving a basis for comparison among the years in the study. From this point on, when the word salary is used, it will refer to the standardized salary. Variables were deliberately kept general, since fragmenting them would have resulted in too few cases per category for findings to be meaningful.

Appropriate statistical tests using SPSS (Statistical Package for the Social Sciences) were chosen and applied to the data in an attempt to verify the hypotheses. After the tests had been performed on individual variables, several variables were combined for testing by summing their scores. For example, a new variable, $E$ score, was formed by adding the scores for library education and subject master's, to obtain a total score for education. Qualification and responsibility scores were treated in the same way to obtain variables $Q$ score and $R$ score. Statistical tests were then run on these combined variables, and all findings were analyzed.

\section{Findings}

A CROSSTABS statistical program was run to determine the number and types of positions advertised each year. The results of this test appear in table 1. One thousand two hundred fifty-four academic library positions were announced in the five years studied. The highest proportion of positions, 28.7 percent, was advertised in 1969. The proportion of advertisements seeking general librarians came down through the years from a high of 20.5 percent in 1959 , to a low of 10.0 percent in 1979. The demand for catalogers was the highest in total; 28.9 percent of all jobs advertised were for catalogers. (Cataloging positions accounted for the highest percentages of jobs advertised in 1959, 1964, and 1969, and the second-highest percentages in 1974 and 1979.) The demand for technical-services librarians remained fairly steady throughout the twenty-year study, but the numbers of circulation librarians needed, never a very high percentage, decreased during the period. This decline was to be expected since circulation is one function that has largely been given over to paraprofessionals. Demand for reference librarians was steady until 1979, then it took a jump 
TABLE 1

TYPES OF POSITIONS BY YEAR

\begin{tabular}{|c|c|c|c|c|c|c|}
\hline & 1959 & 1964 & 1969 & 1974 & 1979 & Total \\
\hline $\begin{array}{l}\text { General } \\
\text { librarian }\end{array}$ & $\begin{array}{c}38 \\
20.5 \%\end{array}$ & $\begin{array}{c}46 \\
17.3 \%\end{array}$ & $\begin{array}{c}39 \\
10.8 \%\end{array}$ & $\begin{array}{c}29 \\
15.0 \%\end{array}$ & $10.0 \%$ & $\begin{array}{l}177 \\
14.1 \%\end{array}$ \\
\hline Cataloger & $\begin{array}{c}58 \\
31.4 \%\end{array}$ & $\begin{array}{c}88 \\
33.1 \%\end{array}$ & $\begin{array}{l}112 \\
31.1 \%\end{array}$ & $22.3 \%$ & $\begin{array}{c}61 \\
24.4 \%\end{array}$ & $\begin{array}{l}362 \\
28.9 \%\end{array}$ \\
\hline $\begin{array}{l}\text { Technical services } \\
\text { librarian }\end{array}$ & $\begin{array}{c}20 \\
10.8 \%\end{array}$ & $\begin{array}{c}35 \\
13.2 \%\end{array}$ & $\begin{array}{c}52 \\
14.4 \%\end{array}$ & $\begin{array}{c}23 \\
11.9 \%\end{array}$ & $\begin{array}{c}28 \\
11.2 \%\end{array}$ & $\begin{array}{l}158 \\
12.6 \%\end{array}$ \\
\hline $\begin{array}{l}\text { Circulation } \\
\text { librarian }\end{array}$ & $\begin{array}{c}14 \\
7.6 \%\end{array}$ & $\begin{array}{c}14 \\
5.3 \%\end{array}$ & $\begin{array}{c}19 \\
5.3 \%\end{array}$ & $\frac{1}{0.5 \%}$ & $\begin{array}{c}5 \\
2.0 \%\end{array}$ & $\begin{array}{c}53 \\
4.2 \%\end{array}$ \\
\hline $\begin{array}{l}\text { Reference } \\
\text { librarian }\end{array}$ & $\begin{array}{c}31 \\
16.8 \%\end{array}$ & $\begin{array}{c}50 \\
18.8 \%\end{array}$ & $\begin{array}{c}55 \\
15.3 \%\end{array}$ & $\begin{array}{c}34 \\
17.6 \%\end{array}$ & $\begin{array}{c}76 \\
30.4 \%\end{array}$ & $\begin{array}{l}246 \\
19.6 \%\end{array}$ \\
\hline $\begin{array}{l}\text { Subject } \\
\text { specialist }\end{array}$ & $\begin{array}{c}14 \\
7.6 \%\end{array}$ & $\begin{array}{c}24 \\
9.0 \%\end{array}$ & $\begin{array}{c}62 \\
17.2 \%\end{array}$ & $\begin{array}{c}45 \\
23.3 \%\end{array}$ & $\begin{array}{c}33 \\
13.2 \%\end{array}$ & $\begin{array}{l}178 \\
14.2 \%\end{array}$ \\
\hline Branch head & $\begin{array}{c}6 \\
3.2 \%\end{array}$ & $\begin{array}{c}8 \\
3.0 \%\end{array}$ & $\begin{array}{c}18 \\
5.0 \%\end{array}$ & $\begin{array}{l}8 \\
4.1 \%\end{array}$ & $\begin{array}{l}16 \\
6.4 \%\end{array}$ & $\begin{array}{l}56 \\
4.5 \%\end{array}$ \\
\hline $\begin{array}{l}\text { Rare-book or } \\
\text { special- } \\
\text { collections } \\
\text { librarian }\end{array}$ & $1.1 \%$ & $\begin{array}{l}1 \\
0.4 \%\end{array}$ & $\stackrel{2}{0.6} \%$ & $\begin{array}{l}8 \\
4.1 \%\end{array}$ & $\begin{array}{l}5 \\
2.0 \%\end{array}$ & $\begin{array}{l}18 \\
1.4 \%\end{array}$ \\
\hline $\begin{array}{l}\text { Bibliographic- } \\
\text { instruction } \\
\text { librarian }\end{array}$ & $1.1 \%$ & $\begin{array}{l}0 \\
0 \%\end{array}$ & $0.3 \%$ & $\stackrel{2}{1.0 \%}$ & $\stackrel{1}{0.4 \%}$ & $\stackrel{6}{0.5 \%}$ \\
\hline $\begin{array}{l}\text { Total } \\
\text { positions } \\
\text { advertised } \\
\text { each year } \\
\end{array}$ & $\begin{array}{c}185 \\
14.8 \%\end{array}$ & $\begin{array}{l}266 \\
21.2 \%\end{array}$ & $\begin{array}{l}360 \\
28.7 \%\end{array}$ & $\begin{array}{l}193 \\
15.4 \%\end{array}$ & $\begin{array}{l}250 \\
19.9 \%\end{array}$ & $\begin{array}{l}1,254 \\
100 \%\end{array}$ \\
\hline
\end{tabular}

upward from 17.6 percent to 30.4 percent. The demand for subject specialists started to go up in 1969 and peaked in 1974, with emphasis on subject specialization in the literature. Branch heads were never heavily represented in the study since they were included only if a substantial portion of their responsibilities were not administrative; but the number of branch head openings fitting this criterion showed a slight trend upward. Rare-book/special-collection librarians and bibliographic-instruction librarians were included because there were a few announcements for these types of positions; but neither category was heavily represented.

CROSSTABS was also used to discover the number of advertisements asking for certain requirements each year. Table 2 details the type of library education required. In 1959, 72.9 percent of the postings mentioned library education only in very general terms if they mentioned it at all. Only 26.0 percent of the candidates were specifically asked for an MLS, with or without ALA accreditation. This number rose steadily throughout the years until 1979, when 97.6 percent of the advertised positions required the library science master's degree. The figure for an ALAaccredited MLS also rose between 1959 and 1969 , but then in 1974 took a jump from 13.3 percent to 52.3 percent, with another jump occurring in 1979 when 77.2 percent of jobs advertised required an ALA-accredited MLS.

The number of candidates asked for a subject master's degree, noted in table 3 , did not rise as steeply as those needing the MLS, but here also a steady rise could be discerned, from .5 percent in 1959 to 27.6 percent in 1979.

The number of candidates asked for library experience (summarized in table 4) likewise rose, with an especially dramatic increase noted between 1969 and 1974 in the percentage of positions requiring specialized experience (from 15.0 percent to 40.9 percent). By $1979,68.4$ percent of all academic library job notices were asking for some kind of experience.

Figures for individual qualifications and responsibilities appear in tables 5 and 6 . The general trend was for the percentages to go 
TABLE 2

Library Education ReQuired by Year

\begin{tabular}{lccccc}
\hline & 1959 & 1964 & 1969 & 1974 & 1979 \\
\hline None listed & 70 & 116 & 115 & 27 & 4 \\
& $37.8 \%$ & $43.6 \%$ & $31.9 \%$ & $14.0 \%$ & $1.6 \%$ \\
Unspecified & 65 & 69 & 26 & 4 & 2 \\
library degree & $35.1 \%$ & $25.9 \%$ & $7.2 \%$ & $2.1 \%$ & $0.8 \%$ \\
BLS & 2 & 0 & 0 & 0 & 0 \\
& $1.1 \%$ & $0 \%$ & $0 \%$ & $0 \%$ & $0 \%$ \\
MLS & 39 & 48 & 171 & 61 & 51 \\
(unaccredited) & $21.1 \%$ & $18.0 \%$ & $47.5 \%$ & $31.6 \%$ & $20.4 \%$ \\
ALA-accredited & 9 & 33 & 48 & 101 & 193 \\
MLS & $4.9 \%$ & $12.4 \%$ & $13.3 \%$ & $52.3 \%$ & $77.2 \%$ \\
\hline
\end{tabular}

TABLE 3

Positions Requiring a Subject Master's Degree

\begin{tabular}{lccccc}
\hline \hline & 1959 & 1964 & 1969 & 1974 & 1979 \\
\hline None & 184 & 264 & 349 & 148 & 181 \\
& $99.5 \%$ & $99.2 \%$ & $96.9 \%$ & $76.7 \%$ & $72.4 \%$ \\
Any subject & 1 & 1 & 3 & 17 & 29 \\
& $0.5 \%$ & $0.4 \%$ & $0.8 \%$ & $8.8 \%$ & $11.6 \%$ \\
Specific & 0 & 1 & 8 & 28 & 40 \\
subject & $0 \%$ & $0.4 \%$ & $2.2 \%$ & $14.5 \%$ & $16.0 \%$ \\
\hline
\end{tabular}

TABLE 4

Positions Requiring Library Experience

\begin{tabular}{lccccc}
\hline & 1959 & 1964 & 1969 & 1974 & 1979 \\
\hline None & 115 & 148 & 229 & 70 & 79 \\
& $62.2 \%$ & $55.6 \%$ & $63.6 \%$ & $36.3 \%$ & $31.6 \%$ \\
Any & 50 & 83 & 77 & 44 & 33 \\
& $27.0 \%$ & $31.2 \%$ & $21.4 \%$ & $22.8 \%$ & $13.2 \%$ \\
Specialized & 20 & 35 & 54 & 79 & 138 \\
& $10.8 \%$ & $13.2 \%$ & $15.0 \%$ & $40.9 \%$ & $55.2 \%$ \\
\hline
\end{tabular}

TABLE 5 
TABLE 6

ResponsibILITIES ReQuiRed By YeAR

\begin{tabular}{|c|c|c|c|c|c|}
\hline & 1959 & 1964 & 1969 & 1974 & 1979 \\
\hline Reference & $\begin{array}{c}34 \\
18.4 \%\end{array}$ & $\begin{array}{c}45 \\
16.9 \%\end{array}$ & $\begin{array}{c}51 \\
14.2 \%\end{array}$ & $\begin{array}{c}85 \\
44.0 \%\end{array}$ & $\begin{array}{c}133 \\
53.2 \%\end{array}$ \\
\hline Cataloging & $\begin{array}{c}24 \\
13.0 \%\end{array}$ & $\begin{array}{l}20 \\
7.5 \%\end{array}$ & $\begin{array}{c}38 \\
10.6 \%\end{array}$ & $\begin{array}{c}47 \\
24.4 \%\end{array}$ & $\begin{array}{c}78 \\
31.2 \%\end{array}$ \\
\hline Circulation & $\begin{array}{c}22 \\
11.9 \%\end{array}$ & $\begin{array}{c}15 \\
5.6 \%\end{array}$ & $\begin{array}{c}15 \\
4.2 \%\end{array}$ & $\begin{array}{c}15 \\
7.8 \%\end{array}$ & $\begin{array}{c}21 \\
8.4 \%\end{array}$ \\
\hline Processing & $\begin{array}{c}8 \\
4.3 \%\end{array}$ & $\stackrel{4}{1.5 \%}$ & $\begin{array}{l}1 \\
0.3 \%\end{array}$ & $\begin{array}{c}8 \\
4.1 \%\end{array}$ & $\begin{array}{c}16 \\
6.4 \%\end{array}$ \\
\hline Acquisitions & $\begin{array}{c}9 \\
4.9 \%\end{array}$ & $\begin{array}{c}12 \\
4.5 \%\end{array}$ & $\begin{array}{c}20 \\
5.6 \%\end{array}$ & $\begin{array}{c}25 \\
13.0 \%\end{array}$ & $\begin{array}{c}21 \\
8.4 \%\end{array}$ \\
\hline $\begin{array}{l}\text { Collection } \\
\text { development }\end{array}$ & $0.5 \%$ & $\begin{array}{c}18 \\
6.8 \%\end{array}$ & $\begin{array}{c}36 \\
10.0 \%\end{array}$ & $\begin{array}{c}59 \\
30.6 \%\end{array}$ & $\begin{array}{c}102 \\
40.8 \%\end{array}$ \\
\hline $\begin{array}{l}\text { Bibliographic } \\
\text { instruction }\end{array}$ & $\begin{array}{c}4 \\
2.2 \%\end{array}$ & $\begin{array}{l}3 \\
1.1 \%\end{array}$ & $\begin{array}{c}6 \\
1.7 \%\end{array}$ & $\stackrel{28}{14.5 \%}$ & $\begin{array}{r}84 \\
33.6 \%\end{array}$ \\
\hline $\begin{array}{l}\text { Faculty } \\
\text { liaison }\end{array}$ & $\begin{array}{l}0 \\
0 \%\end{array}$ & $\begin{array}{c}5 \\
1.9 \%\end{array}$ & $\begin{array}{c}24 \\
6.7 \%\end{array}$ & $\begin{array}{l}28 \\
14.5 \%\end{array}$ & $\begin{array}{c}45 \\
18.0 \%\end{array}$ \\
\hline $\begin{array}{l}\text { Teach library } \\
\text { science }\end{array}$ & $2.2 \%$ & $\begin{array}{c}1 \\
0.4 \%\end{array}$ & $\begin{array}{l}3 \\
0.8 \%\end{array}$ & $1.2 \%$ & $2.0 \%$ \\
\hline A-V work & $1.1 \%$ & $\begin{array}{c}2 \\
0.8 \%\end{array}$ & $1.97 \%$ & $\begin{array}{c}8 \\
4.1 \%\end{array}$ & $\begin{array}{c}19 \\
7.6 \%\end{array}$ \\
\hline Computer work & $\begin{array}{l}0 \\
0 \%\end{array}$ & $\begin{array}{l}0 \\
0 \%\end{array}$ & $\begin{array}{l}8 \\
2.2 \%\end{array}$ & $\stackrel{9}{4} \%$ & $\begin{array}{c}65 \\
26.0 \%\end{array}$ \\
\hline $\begin{array}{l}\text { Administrative } \\
\text { duties }\end{array}$ & $\stackrel{5}{2.7 \%}$ & $\begin{array}{c}13 \\
4.9 \%\end{array}$ & $\begin{array}{l}23 \\
6.4 \%\end{array}$ & $\begin{array}{c}21 \\
10.9 \%\end{array}$ & $\begin{array}{c}52 \\
20.8 \%\end{array}$ \\
\hline Personnel work & $\stackrel{1}{0.5 \%}$ & $\begin{array}{c}9 \\
3.4 \%\end{array}$ & $\begin{array}{c}15 \\
4.2 \%\end{array}$ & $\begin{array}{c}27 \\
14.0 \%\end{array}$ & $\begin{array}{c}46 \\
18.4 \%\end{array}$ \\
\hline $\begin{array}{l}\text { Specialized } \\
\text { subject }\end{array}$ & $\stackrel{1}{0.5} \%$ & $\begin{array}{l}7 \\
2.6 \%\end{array}$ & $\begin{array}{c}15 \\
4.2 \%\end{array}$ & $\begin{array}{l}60 \\
31.1 \%\end{array}$ & $\begin{array}{c}80 \\
32.0 \%\end{array}$ \\
\hline $\begin{array}{l}\text { Specialized } \\
\text { materials }\end{array}$ & $\begin{array}{c}27 \\
14.6 \% \\
\end{array}$ & $\begin{array}{c}32 \\
12.0 \% \\
\end{array}$ & $\begin{array}{c}57 \\
15.8 \% \\
\end{array}$ & $\begin{array}{c}32 \\
16.6 \% \\
\end{array}$ & $\begin{array}{r}60 \\
24.0 \% \\
\end{array}$ \\
\hline
\end{tabular}

upward, with notable increases between 1974 and 1979 in computer expertise, communicative ability, administrative ability, computer work, and administrative duties. The number of postings requiring reference, faculty liaison, personnel work, and work with specialized subjects also increased between 1969 and 1974 , while the number of notices mentioning bibliographic instruction rose dramatically in 1974 and again in 1979 . In the case of only one variable, teaching library science, was the percentage lower in 1979 than it was in 1959.

An analysis of variance using the program ONEWAY was performed to indicate whether there were statistically significant differences among the mean salaries paid in each year of the study. This test, utilizing the Scheffe procedure, found that there were no statistically significant differences between mean salaries paid in 1959 and 1979 and between those paid in 1964 and 1974. For the five years studied, three salary groups emerged: the "low salary" years (1959 and 1979), the "middle salary" years (1964 and 1974), and the "high salary" year (1969). Figure 1 graphs the progress of salaries from 1959 to 1979. Salaries in real dollars rose sharply between 1959 and 1969 and then fell. Although 1979's salary was higher than 1959 's, the analysis of variance showed no statistically significant difference between salaries of the two years. In practical terms, this means that librarians in 1979 were not much better off financially than they were in 1959.

Findings on faculty status were less clear. Table 7 shows the numbers and percentages 


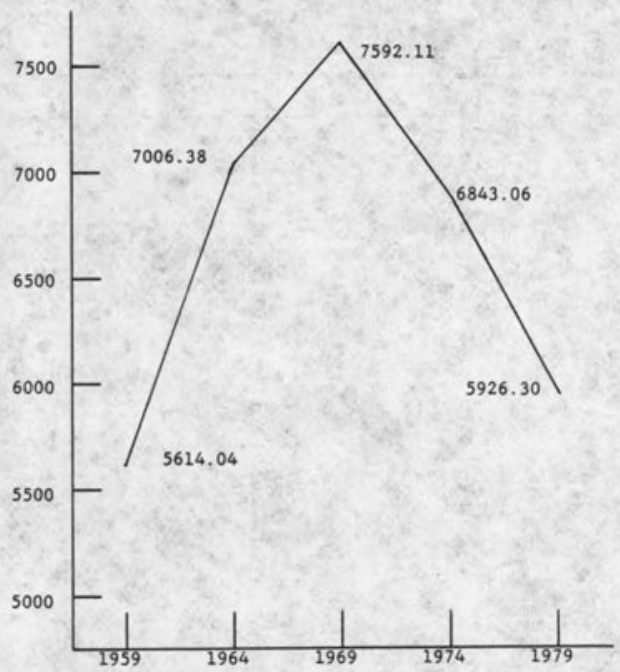

Fig. 1

Mean Salary by Year

of positions offering faculty status by year. Considering the amount of agitation for faculty status since 1959 , a steady rise in these percentages could be expected, with a majority of positions offering faculty status by 1979. However, the percentage totals fluctuated from year to year and never went above 52 percent. Either librarians are not attaining faculty status in the numbers generally believed, or faculty status has become so widespread that employers feel that they no longer need to mention it in a job posting. The truth probably lies somewhere in between.
The library experience and subject master's variables were tested with analyses of variance that proved inconclusive, so they were broadened and retested. Both of these variables had been designed to include three categories depending on how specific the experience or degree requirement was. For the second tests, each variable included only two categories dependent simply on whether or not the variable was required. T-tests were run on these variables to determine whether experience or a subject master's degree indicated a higher salary. Findings of these tests are summarized in tables 8 and 9 . From these tables, it can be discerned that experience was a fairly stable indicator of higher salary while a subject master's degree indicated a higher salary only in the last two years, the time period when more employers were asking for this qualification.

Figure 2 graphs $E, Q$, and $R$ scores (the scores that combine all education, qualifications, and responsibilities into three separate variables) for each year. In all three cases, analyses of variance found statistically significant differences between earlier and later years, with the predominant trend being a steady rise in the scores between 1959 and 1979.

The program SCATTERGRAMS was run in an attempt to discover whether there was any relationship between salaries and $E, Q$, and $R$ scores. The three variables were broken down by year and tested, and statistically significant results were noted in table 10 . What was sought were statistically signif-

TABLE 7

Postrions Offering Faculty Status by Year

\begin{tabular}{lccccc}
\hline & 1959 & 1964 & 1969 & 1974 & 1979 \\
\hline Number & 85 & 73 & 185 & 74 & 112 \\
Percentage & 45.9 & 27.4 & 51.4 & 38.3 & 44.8 \\
\hline
\end{tabular}

TABLE 8

Significant Findings for T-Tests Measuring Salary by Experience

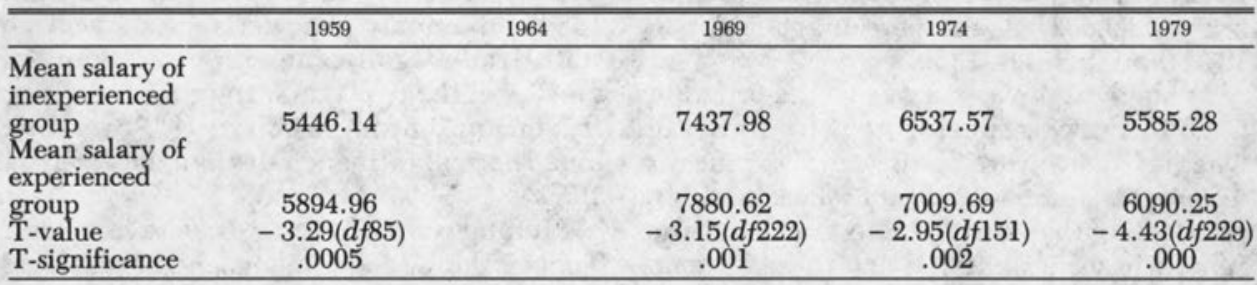


TABLE 9

Significant Findings for T-Tests

Measuring Salaky by Subject Master's Degree

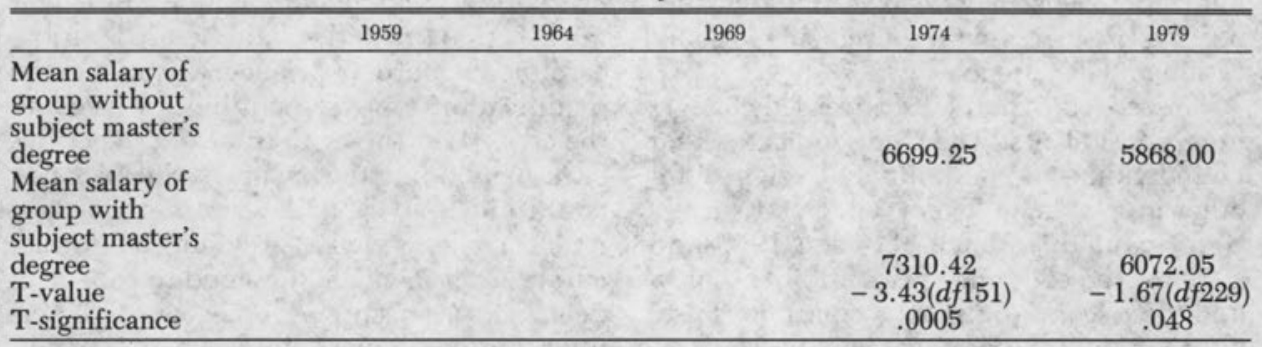

TABLE 10

Correlations between Salaries and $E, Q$, and $R$ Scores by Year

\begin{tabular}{lccccc}
\hline & 1959 & 1964 & 1969 & 1974 & 1979 \\
\hline \multirow{2}{*}{ E score } & & $.22574^{*}$ & .14221 & & \\
& & $.05096 \dagger$ & .02022 & & \\
$Q$ score & .41000 & $.01271^{\ddagger}$ & .04128 & .36908 & .14751 \\
& .16810 & & & .13622 & .02176 \\
& .00172 & & & .00019 & .02085 \\
$R$ score & & .38158 & & & \\
& & .14560 & & & \\
\hline
\end{tabular}

$* r$
$t r^{2}$
$\ddagger$ Significance of $r$

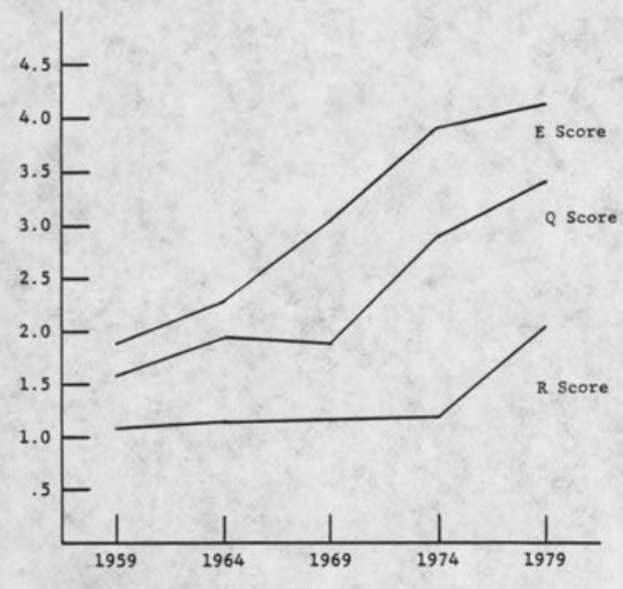

Fig. 2

$E, Q$, and $R$ Scores by Year

icant positive correlations, in other words, cases where the salary went up with the score. Qualifications seemed to be the most important indicator of a higher salary; a higher $Q$ score meant a significantly higher salary in 1959, 1974, and 1979. Education followed with a higher $E$ score meaning a higher salary in 1964 and 1969 . In both cases, however, only a little variation in salary was accounted for by education (as indicated by the $r^{2}$ figures). Also, this variable showed no statistically significant results in the last two years, perhaps because educational requirements became more standardized. Since candidates were asked for a similar education, the salary offered depended on other factors. $R$ score was the least indicative of the three job aspects; a higher $R$ score was equated with a higher salary in 1964 only.

\section{Conclusions}

In terms of the hypotheses, therefore, several conclusions can be drawn. The notices indicated that librarians did have to bring more to their jobs, especially in the realm of education. There was strong evidence that the basic educational requirement for entry into librarianship had become more structured and stringent. Strong evidence also supported the idea that library experience was increasingly necessary to obtain a post as an academic librarian. Some evidence did 
back up the idea that other qualifications were more necessary in 1979 than in 1959, but this evidence was weaker than that supporting the increased requirements for education and experience.

The second hypothesis concerned changes in responsibilities. The study indicated that no individual responsibility outweighed another at any time. There was a statistically significant difference between 1959 and 1979 for the combined responsibility scores, and these scores did show a continuous rise, but the range of scores was very narrow.

The third hypothesis was that benefits were improving in response to new demands. Benefits were studied mainly in terms of salaries, since status proved to be unreliable as an indicator of the value placed on various job aspects. Salaries followed the general cycle of wealth and scarcity in higher education by rising and then falling. Experience and a second master's degree were the only qualifications that commanded higher salaries; no responsibilities were more highly rewarded than others.
Little empirical research has been conducted regarding the changes in academic librarianship, and much remains to be examined. Perhaps a study could be made, using careful safeguards of privacy, to compare the qualifications and responsibilities listed in the advertisements with those of the persons eventually filling the openings. Such a study could aid readers and writers of job announcements as well as providing a more accurate assessment of the condition of academic librarianship. Another research line might be to compare librarianship's condition with that of other professions. An especially interesting project might be a comparison of librarianship with other professions in which women predominate.

A good deal of literature has been published about the role of the academic librarian and the changes in academic librarianship. This literature speculates and offers opinions, but little supporting evidence is provided for any conclusions. It is hoped that this study will be a first step in providing that evidence. 